\title{
LET'S GET THE EMBATTLED SPOUSES OUT OF THE TRENCHES
}

\author{
Paul W. Alexander*
}

Lawyers are sometimes accused of being unable to see the woods for the trees. In my book there are at least a couple of other callings equally or more chargeable with this failing. But it is a common human failing, productive of many evils, just one of which is the too-frequent miscarriage of justice.

So, instead of scrutinizing each individual tree, suppose we take a little look at the woods, with the prayerful hope that we may then be a little better able to decide which of the trees are useful, bear edible fruit, and are a friend to man, and which are merely obstacles to be bumped into.

\section{I}

Forgive me if I remind you that the history of man is largely a history of conflict-racial, religious, tribal, national, local, political, personal. You and I have just lived through a generation of international conflict; and it looks as if we were in for a couple more such generations. And, of course, all of these conflicts are generated and nourished in men's minds.

One of the greatest living philosophers, Eduard C. Lindeman, professor emeritus of philosophy at Columbia, has said: ${ }^{1}$

A healthy-minded person is one who knows that he will never be released from conflict. Where there is life there is conflict and where there is no conflict there is death. The dream of a life minus strains, tensions and conflicts is exactly that, a dream. Health is to be found, not in escapes from conflict, but rather in making certain that the conflicts which do engage our attention and energies move onward to higher planes. To remain for long on the same level of conflict is to deteriorate. War, for example, is a low level form of conflict which when prolonged causes deterioration. It is not to be supposed that world government so firmly organized as to eliminate war would by that token eliminate conflict. It would, however, precipitate conflicts of a higher order.

It is generally believed that no form of conflict takes more lives, causes more suffering, than war. Yet I sometimes wonder. There are infinitely more persons than nations. Probably not to the warriors engaging in the international conflicts, but perhaps to this vast multitude of persons at home, the personal conflicts loom larger than national conflicts, and can and often do cause greater distress and deterioration.

* Judge, Court of Common Pleas, Division of Domestic Relations and Juvenile Court, Lucas County (Toledo), Ohio; Chairman ABA Special Committee on Divorce and Marriage Laws and Family Courts; Chairman Interprofessional Commission on Marriage and Divorce Laws; Acting Chairman Legal Section, National Conference on Family Life; Past President, National Council of Juvenile Court Judgcs; Past President, National Conference of Juvenile Agencies.

${ }_{1}^{1}$ Mental Hygiene and the Moral Crisis of OUR Time ${ }_{4}$ (Hogg Foundation, 1952). 
In prehistoric times, we are told, these personal conflicts were resolved by fighting it out, presumably with stones, clubs, and spears. With the beginning of history we learn about the institution of judges and courts to settle personal clashes in less barbaric fashion. Through the ages it is probable that more and more of these personal combatants obtained judicial decision of their disputes-but not all. Would you find any significance in the fact that the Anglo-Saxon word for "judgment, decision," is our word "ordeal"?

You are all familiar with the ordeals by poison, fire, boiling water, battle, etc., which prevailed in the Dark Ages, so fraught with superstition and misconceived reliance on the supernatural. (Incidentally, as a youthful prosecutor of criminal cases I used to think wistfully how simple and convenient was the ordeal by water. You just threw the accused into the water. If he floated he was guilty. If he sank he was innocent. In either event he was sunk as far as the prosecutor was concerned.) During the Middle Ages these ordeals appear to have fallen into desuetude in Europe, though they still persist among some savage tribes elsewhere. In England they were abolished under Edward III in the thirteenth century-all except the wager of battle. In this form of "trial" the "litigants" fought with batons and staves on an enclosed piece of ground before a judge and had to keep at it until the stars came out unless one was sooner defeated or killed. As late as I8I8 a defendant in England demanded and had to be allowed to resolve his personal conflict in this manner. Thereupon wager of battle was formally abolished.

But was battle quite abolished or merely modified in form? The law had generously provided that women, priests, old men, the lame, and the blind could do battle by champions. Today parties seeking lawful resolution of their personal conflicts do battle on an enclosed piece of ground called a court room, before a judge, with lawyers as their champions.

"Do battle?" Sorry, that's what I said. Federal Judge Jerome Frank, of New York City, in his recent book, Courts on Trial," calls a lawsuit a "kind of fight or combat." Supreme Court Justice Bernard Botein, also of New York City, in his autobiography just published," titles his sixth chapter: "Most Trials are Private Fights." Quotations like this could be multiplied indefinitely and I know of no trial judge who would dissent. After I5 years and thirty-odd thousand cases of embattled spouses seeking to resolve their marital conflicts in the trenches of the litigation process, I take no exception.

And Judge Botein points up the observation of every divorce court judge when he says, speaking of domestic relations cases:4

The usual litigation wounds are chafed raw by the parties' proximity, intervention of relatives, emotional strains, and other factors.

The bitter hatred which the parties hold for each other seems to infect their lawyers. The most decorous of lawyers snap and snarl at one another. Lawyers who ordinarily

${ }^{2}$ Princeton University Press, 1949.

${ }^{3}$ Trial Judge (I952).

- Botein, op. cit. supra, at I44-I45. 
submit very restrained papers drain their vocabularies of vituperation when dictating affidavits in a matrimonial action. Attorneys capable of drawing the most subtle distinctions see only blacks and whites in such litigation.

Judge Botein characterizes the "competitive, adversary concept of litigation" as "the private fight concept" and "the self-help theory in trials" and says:"

In these contests the state has been relegated largely to the function of furnishing the stadium and the referees; of booking, staging and deciding these civilized fights; and of participating, if at all, in nonpartisan fashion. This role might be accepted superficially, although not justifiably, in civil litigation, on the ground that the state has no direct stake in the result; ... [But] what about the matrimonial action, in which the custody of children, wards of the state, hangs in the balance?

Lloyd Paul Stryker, of New York, a practical, realistic trial lawyer if there ever was one, deems worthy of quotation in the New York County Bar Bulletin this observation of Judge Botein:" "I know of no class of decisions rendered in our court which have greater importance than those involving the awarding of custody of children."

It is in the matrimonial, divorce, domestic, children's cases that the state does have a stake and a very real one. It is here, if anywhere, that the truth and the whole truth should be revealed, not concealed. And it is here that the "private fight concept" of litigation can and usually does wreak its most devastating damage. Lawyers as well as laymen are becoming increasingly outspoken in their recognition of the defects of our present system of adversary litigation. You have all had your own experiences and gathered your own impressions. For the observations of one experienced and fearless judge I suggest you read Jerome Frank's Courts on Trial. His main thesis is that "trial-court fact-finding is the soft spot in the administration of justice." And Judge Botein titles his fifth chapter: "The Truth Is Not Always in a Trial." In his chapter treating family cases he laments ${ }^{7}$ that trial courts are not equipped to probe such cases, "to investigate homes, reputations, and environment," obtain psychiatric help, etc. In order "to put an end to the prevailing practice which generally gives the child to the successful party, as a sort of prize of war," he favors current proposals for "trained social investigators and psychiatrists" for every court entertaining this jurisdiction.

The standard juvenile court is so equipped. With its specially trained staff it does a highly satisfactory job, with almost a complete absence of adversary procedure. The private fight concept is banned. Conflict is resolved peacefully. Now "a vital function of a trial court is to resolve conflict peacefully." isn't it good sense to adopt these proposals in trial courts handling family conflict in divorce, separation, and annulment actions?

\footnotetext{
Id. at 96.

Id. at 27 .

${ }^{7} I d$. at 27 I et seq.

${ }^{8} \mathrm{Id}$. at 85 .
} 
The establishment of the World Court and the United Nations was designed to raise international conflict to a higher level. In the area of private conflict law courts lifted litigants out of the ordeal into the adversary trial. The inauguration of chancery proceedings elevated the resolution of certain personal conflicts from the rigid common law to a higher order. Only a half century ago, the child in conflict with authority was rescued from the adult criminal court and his multiform problems were placed for resolution in the non-adversary, therapeutic or healing juvenile court; and that has been hailed as "the greatest single advance in AngloAmerican jurisprudence since Magna Carta." No, those are not the words of an over-zealous juvenile court judge. They are the words of one whom the American Bar Association Journal has characterized as "the pre-eminent legal scholar of the world," Roscoe Pound!

Why stop there? Why not rescue the embattled spouses as well as their battered children (battered emotionally and economically if not physically), why not rescue the ailing families of America from their almost certain doom under "the self-help theory in trials"? Why not elevate the resolution of their conflicts from the "competitive, adversary concept of litigation," from the "private fight concept," to the affirmatively helpful, noncompetitive, therapeutic concept that motivated the establishment of the juvenile court? Why should the child have the benefit of this treatment and not his parents? Delinquency and divorce both result from intrafamily conflict. Commonly the treatment that solves one problem is efficacious for the other.

Did it ever strike you as at least mildly absurd that the law should proclaim its interest in the preservation of the family unit and express its desire to see the disunited reunited, and then when the parties go to law for relief the law, instead of helping them reunite, forces them to fight each other? Of course, everybody knows that in an overwhelming majority of divorce cases the plaintiff only has to do some routine shadow-boxing and wage a sham battle against the little man who isn't there. Nevertheless the requirement that the plaintiff charge her spouse publicly with sin or crime or both and then bring witnesses to testify openly against himthis pitting of one against the other in battle array-is demonstrably not conducive to "peaceful resolution of their conflict."

${ }^{\circ}$ Dr. John S. Bradway, Duke University Law School, in his famous article, "The Myth of the Innocent Spouse" (II Tulane L. Rev. 377, 387, 289-390 (1937)) pointed out that litigants "see divorce not as a solemn impersonal decree of death for a socially useless family, but as a battle in which one individual victorious spouse gains the right to remarry and perhaps a substantial property settlement. . . The litigation process, devised in a day when the 'water-tight compartment' theory of the social sciences prevented effective cooperation among neighboring professional groups, serves fairly well to disclose symptoms-what the defendant did; it is unable to cope with the real causes. Litigation, a substitute for trial by battle, provides an arena in which contending parties can settle claims of right and wrong. To employ this crude device, which in a proper case will lead to family dissolution at the request of one of the parties, as a means toward the rehabilitation of a domestic unit already shaken by dissension, is somewhat like taking a wateh to be repaired by a blacksmith. A more sensitive institution is needed to deal with what are now legal imponderables. 
They are in court because they have already had their fill of battling. They've argued and threatened and called names until one or both decided they can't take it any longer. So they break up. Then when they get to court the namecalling must start all over again. And the fact that so many defendants do not defend themselves may not be taken as proof they don't mind being accused and called names. It is not at all uncommon for a defendant to seek a conference with the judge to tell him: "I don't care so much if she gets her divorce, but I ain't the heel she makes me out to be. I never done none of those things she says about me." And when it is explained to him that the law has always supposed it necessary to predicate divorce only upon proof of the other spouse's sin or guilt he turns away in angry frustration, no doubt agreeing heartily with Mr. Bumble in Oliver Twist: "If the law supposes that, the law is a ass-a idiot."

Even if the law had no concern for the preservation of family life it is hard to see how it accomplishes anything by intensifying the antagonism that broke the family. But when the law, through both opinion-writers and statute-givers, so loudly proclaims its interest in the family, it seems to me that if it is sincere it should have an equal interest in the spouses and children who comprise the family, and must find ways to inhibit this antagonism before it reaches the breaking point, or nullify or at least mitigate it after it has passed the breaking point. But in such an effort it appears the law will continue to stymie itself as long as it continues to make sin or guilt or fault the criterion of divorce. As an observer in the front-line trenches (or the foxholes, if you are of a later generation) in the war between the spouses, may I be permitted to express the ever-deepening conviction that to continue to base divorce upon proof of fault or guilt makes the private fight concept and the adversary proceeding inescapable, which, in turn, makes the court inevitably more of a punitive than a healing agent, and makes almost impossible the court's attempts at preventive justice. This conclusion is born of experience sitting contemporaneously in the adversary divorce court and the non-adversary juvenile court. ${ }^{10}$

\footnotetext{
"The initial question for the court in a divorce case should be, not only what the parties want, but what is for the best interests of the family."

And in the same year (Why Pay Alimony?, 32 IIL. L. REv. 295, 298 n. 24 (x937)) Dr. Bradway said: "Litigation, the legitimate offspring of trial by battle . . . and with unrestricted murder as a distant ancestor ... produces in the minds of present day litigants a competitive desire to excel as if in a sporting contest. . . . The law in the field of domestic relations deals inevitably with personalities as well as with events. It is not well equipped for such a task."

And writing in the Iowa Law Review in 1943 (Family Dissolution-Limits of the Present Litigious Method, 28 Iowa L. REv. 256, 264, 265 (1943)), the same authority said: "Another difficulty" lies in the contentious character of litigation. By the time a divorce case comes to court, there is enough difference of opinion between the parties to satisfy most litigious inidviduals. . . . It would seem that the inability of the parties to live together in normal fashion should be sufficiently shocking without making the black mark of a crime on the public record of the defendant. But the irritating factors do not stop here. . . . It is, perhaps, impossible of proof, but one may imagine that litigation has a hand in barring at least some reconciliations." [I nominate that last as the understatement of the ycar r943!]

${ }_{10}$ It has therefore been doubly encouraging to me to discover as I went along that others before me who are scholars and not mere practitioners have been voicing the same ideas, albeit more cloquently. For instance, the distinguished Helen Silving, of the University of Vienna, in 1944 pointed out (Divorce
} 
Is it perhaps a little brash for a juvenile court judge to entertain the thought that the trial courts (superior, circuit, district, supreme, common pleas, etc.) in handling their divorce and domestic relations dockets might profitably condescend to take a leaf from the book of the lowly juvenile court? Here's what Roscoe Pound has to say on the subject: $:^{11}$

Already there is a movement to substitute healing procedures, devised to save households, for the combative proceedings operating to make disruption permanent; and this movement is the result of experience gained in the juvenile courts and wisely directed activities of judges of juvenile courts. Not only in what it has done in its own sphere but in indicating to us a larger sphere in which there is much to be done and in showing us something of the way to do it, the juvenile court has made lasting contributions to the administration of justice.

Then why shouldn't we substitute the non-adversary, helpful proceeding for the combative, harmful litigation process? Because it is too new? Former Juvenile Judge Kenneth D. Johnson, now Dean of the New York School of Social Work of Columbia University, speaking at the observance of the Golden Jubilee of the Cleveland Juvenile Court, said:12 "The universal acceptance of the belief that people can be IN NEED OF HELP without being at fault is a relatively new belief." Relatively new, yes, but also becoming relatively universal.

\section{III}

The non-adversary proceeding is already familiar to the legal profession. The public may have the idea that a lawyer must always be serving as an advocate for somebody against somebody else. But any lawyer can think of plenty of proceedings that are non-adversary, e.g., most probate practice, real estate practice, the forming and reorganizing of corporations, most contract work, trust work, tax practice, etc.

Obviously, in such proceedings, even where court process may be invoked, the object is not to have the court order somebody to do something or render a judgment against him. And neither is this the object of a divorce action. It is not an order to the defendant to do something. ${ }^{13}$ It is not a judgment against him, even though we carelessly call it that. (For one thing, how could a court render a valid judgment against a person without having jurisdiction of that person?) Yet we commonly talk-and think-as if divorce were an action in personam instead of an operation on a res, a severance of the legal bond created by the state and still in esse after the parties have themselves severed the biological, emotional, social, economic and other bonds (except, in some faiths, the religious bond).

Without Fault, 29 Iow L. REv. 527, 557 (1944)) that: "The development of modern law is marked by a tendency toward restriction of the principle of fault or guilt," and in concluding, stated: "Nowhere is the justification for such a change of attitude more obvious than in the law of divorce. The psychology of marriage is less accessible to the judge than that of other domains of the law. Agenor Krafft's words are well in point: '.. . Is it really believed that spouses who have engaged in litigation, sometimes for years, are going to take up their marital relationship because seven federal judges have decided, sometimes in a few minutes, that they ought to try again, that it was not proved, etc. . . ."

${ }^{11}$ The Challenge of the Juvenile Court, The Juvenile Court Judges Journal, January, 1952, p. 18.

${ }^{12}$ The Juvenile Court-A Noble Adventure, The Juvenile Court Judges Journal, July, 1952, p. 34 .

${ }^{15}$ I speak only of divorce, not of alimony, custody, or other incidental issues. 
Although we are often told that divorce dissolves a status I have never heard anyone remark that divorce dissolves a couple of statuses. Yet so far as I can learn, nobody has discovered a satisfactory method of dissolving the status of plaintiff and leaving defendant in statu quo ante bellum. Just how could a court in Maine dissolve a status in California anyway? But it could sever the bond which, unlike the iron vinculum of the humorous story, is really quite elastic, for it stretches from Maine to Calfornia and still unites the parties-legally. And of course Maine has jurisdiction over that part of the bond within its borders; and a tie is effectually severed whether it be cut at the east or west end, or in the middle. And since the action for divorce is not really against the person of the defendant, but operates solely upon the res, why does it have to be adversary in form and practice? Does it make any more sense for plaintiff to sue the other spouse than it would for her to sue the res? Well, it's always been that way in this country, and to adopt the more logical as well as more salutary non-adversary concept would be something new.

Now we lawyers as a class are, as I have said elsewhere, ${ }^{14}$ peculiarly susceptible to neophobia. Maybe that isn't the word the Greeks had for it, but well they might have, for if there's one area in which, with one possible exception, we stand pre-eminent, it is in our dread of something new. This is very easy to understand, for we come by our allergy to change through both training and tradition. We are taught stare decisis (to stand by the decisions). We would like the law static, inflexible, unchanging, so that we could predict with absolute certainty the outcome of any controversy, the exact resolution of any conflict. In our zeal for government of laws, not men, we would reduce the courts to the status of slot-machines: in would go the problem, out would pop the solution. Judges and juries would be mere cogs in the machine. There would be no room for error, no human fallibility, eventually no humans. The only flaw seems to be that there would be no room for human problems either.

The many proposals to elevate the family conflict level are what the famous Philadelphia trial judge, Curtis Bok, would call "not reform, but a worthy exercise in discovery and maturity." They are innovations; but even innovations are suspect (and not alone in the legal profession). They may rock the boat, they may upset the applecart, the established order.

To quote philosopher Lindeman again: "I have noticed that in the careers of successful men an important factor in their success could be attributed to their capacity as innovators. They were not 'Yes-Men.' "15 Do you suppose we lawyermen might be more successful if we were to become a little less the "Yes-Men" of the established order ("Yes-Men" not because it works so perfectly, but simply because it is established) and a little more the innovators in the matter of resolving human conflict?

\footnotetext{
14 Alexander, What Is a Family Court, Anyway?, 26 Cons. B. J. 243 (Sept. I952).

${ }^{15}$ Lindeman, op. cit. supra note 1 , at 16 .
} 
Take the medical profession. They are concerned with bodily ills. In delinquency and divorce we are concerned with behavior ills. The doctors don't treat their ills the same today as they did a few centuries, even a few decades, ago. Fancy a doctor smugly asserting: "The accumulated wisdom of the ages has shown our present method is the best way to handle these cases, and we refuse to deviate from it and we resent any attempt to improve upon iṭ!"

No, they are not hidebound by tradition; they do not claim they know all that needs to be known about the best way to do their job. Almost daily we read of near-miracles performed by the medical profession. The doctors succeeded because they were innovators. They willingly discarded the methods of yesteryear. The old methods may have been time-tested and proven by thousands of cases, but nevertheless the doctors have constantly sought better methods and procedures. And they have dared to try them out. True, they have embraced new ideas, new thinking, with due caution and all necessary safeguards; they have first tested them out thoroughly, as rightly they should. The point is, they are not afraid. They have not used caution as a cloak for cowardice.

There are some who hold that the displacement of adversary proceedings in divorce cases would rule out the lawyer, because of the popular fallacy indicated above that the lawyer's only job is to serve as an advocate for somebody against somebody else. Few things could be further from the truth. When the lawyer appears in juvenile court, perhaps originally with the idea of being an advocate, he remains as a collaborator in a non-adversary proceeding. No matter how bellicose or anxious he may be when he comes in to earn his fee by "springing" the child in a delinquency hearing, he almost invariably remains to work with rather than against the court workers and everybody else. Without betraying his client he helps the court determine the best solution, then "sells" it to his client-after all, he is an officer of the court. And he can often do things which the court itself is incapable of doing, because he is personally known to the client and has already gained the client's confidence-otherwise why would the client have retained him? This is not a starry idealization of what should be. It is a narration of fact, proven by many years of experience in the standard juvenile courts of the land. And experience has shown that the same results obtain in divorce cases in family courts. ${ }^{16}$

If the private fight concept be abandoned in family cases, what would take its place? One short answer is that the juvenile court pattern has already been followed to some extent in a few courts and could be adapted to any court. To describe it in detail we would have to inflict upon you another article. ${ }^{17}$ Facts are investigated with the cooperation of the attorney or attorneys, reported to the

${ }^{20}$ See Alexander, supra note 14.

${ }^{27}$ See Alexander, Confessions of a Very Juvenile Judge, in Yearboox, Natjonal Probation AssociaTION I24 (194I); Of Juvenile Court Justice and Judges, 46 J. Mich. STATE Medical Soc'y io 49 (1947); The Family Court of the Future, 36 J. AM. JUD. Soc'Y 38 (I952), reprinted from YEARBooK op the National Council of Juvenile Court Judges 89 (I95I); What Is a Family Court, Anyway?, supra note 14. 
court and discussed informally, the object being to determine, what is best for the family.

Obviously this opens the door, not to rumor, hearsay, suspicion, etc., but to what is called "social evidence," evidence gathered from varied sources and professions, including opinions of experts when indicated, designed not to convict or lead to punishment, but to ameliorate and possibly improve the personalities of the parties whether or not they are to continue in the married state.

It was one of the world's great lawyers who said: "A perverse temper, and a discontented, fretful disposition, wherever they prevail, render any state of life unhappy." He said this a couple of thousand years ago and his name was Cicero. Another of the world's great lawyers, Roscoe Pound, who would have the law serve to prevent needless tragedies in the divorce court, has said, somewhat more recently: "In effect, what there is in the way of preventive justice . . . is achieved not by legal, but by social agencies. It is done, for the most part, not by the agencies of the law, but by the social workers." And as to social evidence, the dean of deans on the law of evidence, John $H$. Wigmore, instead of shaking his head and raising melancholy objections, said, 30 years ago: "The great thing is that in the court of the next generation, with its staff of social workers, those materials and methods will be the main ones and our present technical rules will have gone by the board."18

When such "greats" as these find an idea worth entertaining, who are you and I to scoff at it!

${ }^{38}$ Quoted by Dean Johnson in The Juvenile Court Judges Journal, July, 1952, p. 33. 